\title{
Green Economy and Sustainable Development: Concepts, Public Policies and Role of Central and Local Government
}

\author{
Abdul Mubarok ${ }^{1}$, Hartuti Purnaweni ${ }^{2}$ \\ \{abibarok20@gmail.com ${ }^{1}$ \} \\ Universitas Diponegoro, Indonesia ${ }^{1,2}$
}

\begin{abstract}
The concept of green economy could be a worldwide natural concept and is closely related to the concept of sustainable development. The concept of maintainable development could be a concept that points to form a adjust between improvement measurements, such as financial, social and natural. Both concepts are very popularly used in western countries and have long been implemented by the Indonesian government. In the context of climate change and green economy, Bappenas has propelled the Indonesia Climate Change Sectoral Roadmap (ICCSR) which contains a nine-sector procedure, specifically ranger service, vitality, industry, transportation, squander, agribusiness, marine and fisheries, water assets, and wellbeing. In connection with the ICCSR, the role of the Central Government and Regional Government is very important and dominant. This article aims to determine: 1) the role of the central government and regional governments in overcoming environmental problems by using this concept with a public policy approach in nine integrated sectors; 2) supporting and inhibiting factors in implementing green economy policies; and 3) the impact of green economy policies. This article uses a qualitative descriptive research approach. The collection of data through in-depth interviews with informants at Department of Environment and Forestry of Central Java Province with snowball sampling techniques, documentation and field observations.
\end{abstract}

Keywords: Green Economy, Sustainable Development, Public Policies, Central and Local Government.

\section{Introduction}

The green economy is characterized as economy that points at decreasing natural dangers and environmental shortages, which points for feasible advancement without debasing the environment. It is closely related with biological financial matters, but contains a more politically connected center [1][2][3]. The 2011 UNEP Green Economy Report argues "that to be green, an economy must not as it were be proficient, but too reasonable. Reasonableness infers recognizing worldwide and nation level value measurements, especially in guaranteeing a fair move to an economy that's low-carbon, asset proficient, and socially comprehensive" [4]. The three economic fairness concepts will more explain below:

a) A low-carbon economy (LCE), low-fossil-fuel economy (LFFE), or decarbonized economy [5] is an economy based on moo carbon control sources that subsequently 
contains a negligible yield of greenhouse gas (GHG) emissions into the biosphere, but particularly alludes to the nursery gas carbon dioxide [6].

b) Resource efficiency means utilizing the earth's constrained assets in a economical way whereas limiting impacts on the environment. It permits us to form more with less and to provide more noteworthy esteem with less input [5].

c) Social inclusion has been defined by the World Bank as "The method of moving forward the terms for individuals and bunches to require portion in society" or more absolutely "The handle of making strides the capacity, opportunity, and nobility of people, disadvantaged on the premise of their personality, to require portion in society" [5].

Social inclusion is multidimensional: it envelops social, political, social and financial measurements, and works at different social levels. The foremost significant viewpoints can be clustered beneath three interrelated spaces: markets, administrations, and spaces. The three spaces speak to both boundaries to and openings for consideration. It is additionally social: it is the item of unequal control relations in social intuitive. At last, social incorporation is energetic, it impacts individuals in different ways and to contrasting degrees over time and basically depends on and impact people's capacity, opportunity and respect which are unequally dispersed among social bunches.

The concept of green economy could be a worldwide natural concept and is closely related to the concept of economic improvement since green economy can be as a primary back to reach the sustainable development goals (SDGs) are a collection of 17 worldwide objectives set by the Joined together Countries Common Gathering in 2015 for the year 2030. The SDGs are part of Resolution 70/1 of the United Nations General Assembly, the 2030 Agenda [7][8][9][10].

\section{Research Method}

This article uses a qualitative descriptive research approach. The collection of data through in-depth interviews with informants at Department of Environment and Forestry of Central Java Province with snowball sampling techniques, documentation and field observations as primer data, while secondary data were obtained from various sources.

\section{Result and Discussion}

In the context of climate change and green economy, Bappenas has launched the Indonesia Climate Change Sectoral Roadmap (ICCSR) which contains a nine-sector strategy, namely forestry, energy, industry, transportation, waste, agriculture, marine and fisheries, water resources, and health. In connection with the ICCSR, the role of the Central Government and Regional Government is very important and dominant.

The role of the Central Government has taken many concrete steps taken by various sectors to support the implementation of a green economy. Various programs in agriculture, for example the method of saving water plantations which can produce more rice with less water and costs (System Rice Intensification/SRI), livestock waste management for biogas and organic fertilizer, utilization of plantation waste for organic fertilizer and the use of palm oil for biodiesel has been carried out. In addition, the use of renewable energy to meet the electricity needs of the community through the development of community-scale micro-hydro, 
as well as the use of solar electricity for households and street lights has been implemented in various regions. The use of gas as a step to support the green economy movement for public transportation has also begun. The Indonesian government and several other countries such as China, Kenya, India and South Korea take steps to "green" development in various fields but not comprehensively.

Strategic environmental issues that occur in Central Java Province are Semen Indonesia in Rembang, Save Slamet in Baturraden Banyumas, Batang Steam powered Electric Generator (PLTU) and waste issues as well as various environmental impacts of environmental damage such as floods and landslides that regularly occur every year. For this problem the Central Java Government must play an active role through various policies that support a green economy. The Central Java Government through its environmental and forestry office issued a funding policy for types of off-farm forestry business, namely the processing of wood forest products, and non-wood forest products, as well as the business of providing production facilities such as the business of procuring certified forestry plant seeds, and making organic fertilizer. But this policy has a very minimal role in restoring the existing natural damage but at least a little to slow down the damage to nature, it needs a comprehensive policy that can overcome environmental problems completely. There are several factors that cause green economy policies are not yet comprehensive and optimal, including: 1) policy standards and objectives to be achieved are not yet clear and detailed; 2) the characteristics of the implementing agency are inadequate, both in terms of the division of tasks and authority; monitoring and evaluation; and standard operating procedure (SOP); 3) relationships between organizations are well established; 4) the attitude of the implementers does not support the successful implementation of green economy policies; 5) the characteristics of the implementing agent are sufficient and 6) social, political and economic conditions have not yet supported the implementation of green economy policies.

\section{Conclusions}

The concept of green economy is a global environmental concept and is closely related to the concept of sustainable development because green economy can be as a main support to reach the sustainable development goals (SDGs) are a collection of 17 global goals set by the United Nations General Assembly in 2015 for the year 2030. The Indonesian government take steps to "green" development in various fields but not comprehensively. Then, the impact of green economy policies has not been felt because the policy is not comprehensive.

\section{References}

[1] "United Nations Environment Programme (UNEP) Archived from the original on 27 March 2016.".

[2] L. R. Kahle and E. Gurel-Atay, Communicating sustainability for the green economy. ME Sharpe, 2013.

[3] J. T. Buseth, "The green economy in Tanzania: From global discourses to institutionalization," Geoforum, vol. 86, pp. 42-52, 2017.

[4] UNEP, "Towards a Green Economy: Pathways to Sustainable Development and Poverty Eradication," 2011.

[5] "No Title.". 
[6] IPCC, "Climate Change 2014: Synthesis Report. Contribution of Working Groups I, II and III to the Fifth Assessment Report of the Intergovernmental Panel on Climate Change. Core Writing Team, R.K. Pachauri and L.A. Meyer (eds.)," Intergov. Panel Clim. Chang., 2014.

[7] U. N. - S. D. knowledge Platform, "Transforming our world: the 2030 Agenda for Sustainable Development."

[8] F. Kern, "Implementing the green economy," Ökologisches Wirtschaften-Fachzeitschrift, vol. 28, no. 3, pp. 20-22, 2013.

[9] L. Levidow, "What green economy? Diverse agendas, their tensions and potential futures," 2014.

[10] W. Lih-Cnyi and L. Chun-Hse, "The Effect of Global Green Economy on Taiwan's Environment-Related Goods Export,” 2014. 